UDK 528.085.421

\title{
INVESTIGATIONS INTO THE ACCURACY OF ANGLE CALIBRATION
}

\author{
Vytautas Giniotis, Mindaugas Rybokas, Petras Petroškevičius \\ Dept of Geodesy and Cadastre, Vilnius Gediminas technical university, \\ Sauletekio al. 11, LT-10223 Vilnius-40, Lietuva, \\ el.paštas: gkk@ap.vtu.lt
}

Received 2005 2004, accepted 14072004

\begin{abstract}
Technical possibilities to create equipment for the calibration of flat angles are discussed in the article. The angular standard measure, the radian, has not been realised as a standard unit until now. Nevertheless, the unit of angular measure in degrees is used as the geometric measure of length in geodesy, machine engineering and other branches of industry - by multiangular prisms - polygons with an autocollimator, rotary tables, circular scales, etc. It should be noted that these angle measures are calibrated against the upper level measures (etalons) only at the several intervals depending on the number of sides (angles) of the polygon or the other standard measure. The methods of calibration of constant angle value in full circle are used as well. At the same time geodetic instruments, rotary tables of metal cutting tools and instruments, rotary encoders have a great number of discrete values. These values between the calibrated points remain unknown during calibration. The information received during calibration relative to all the information available can be evaluated using information entropy. The equipment of calibration permitting to select significantly more information would be essential for better accuracy assurance of instruments used in machine engineering, geodesy, building structures. Theoretical and technical background for justifying and developing such equipment for angular accuracy calibration is presented here. A modern scientific and technical background validates this concept.
\end{abstract}

Keywords: calibration, circular scale, etalon, angle, accuracy.

\section{Introduction}

The angle measuring instruments produced by many Western companies were used in Lithuanian factories and institutions for a long time. Circular scales were produced using mostly circular dividing machines produced by VEB Feinmess Dresden company. Original circular dividing machines were constructed and put into practice at the Experimental Scientific Research Institute of metalcutting tools (ENIMS) Vilnius branch. The production of circular scales is straightforward linked with the methods and means of angle measurements. These methods have not altered much in time being in their general approach. Especially it is valid for circular scales measurement. High accuracy and discretion of circular scales measurement remain an acute problem even nowadays.

\section{Measurement of circular scales}

Measurement of circular scales has its own specific problems. Additional features that help perform this measurement is the fact the sum of the full circumference is always equal to $360^{\circ}$. This enables to calibrate circular scales using one reference angle throughout the whole circumference and thus to analyse the errors of angular values as the difference between the real values of reading devices and the values of calibrated reference angle. In the metrology of circular scales that was mostly developed in geodesy and astronomy, there is such terminology used as "error of the scales diameter". The "diameter" means the line going through the strokes lying on the opposite side according to the centre of the scale. In most geodetic measurements the errors of "diameters" or the errors between the "diameters" are determined. It helps to avoid the errors due to the scale eccentricity to be measured and the trajectory of axis rotation. The error of "diameters" can be expressed by the algebraic sum of errors of two opposite strokes [1,2]:

$$
\Delta\left(\varphi_{\Sigma}^{i}\right)=\Delta \varphi_{\Sigma}^{i}+\Delta \varphi_{\Sigma}^{i+180^{0}}
$$

where $\Delta \varphi_{\Sigma}^{i}$ and $\Delta \varphi_{\Sigma}^{i+180^{\circ}}$ are the errors of two opposite strokes.

The errors of circular scales are determined by some methods approved in written standards:

- $\quad$ the method of approximation;

- $\quad$ the method of opposite matrix;

- $\quad$ the method of Yeliseyev (or Heiwelynk);

- $\quad$ the method of Wild.

These methods are legalised by the written standard [3], the exception being that the method of Heiwelynk is used more widely in Western countries.

The following methods of angular scales calibration are used in machine engineering and instrumentation:

- the comparison of the angular values of the scale strokes with the values of the reference scale or other reference measure of angle;

- the comparison of the angular position of strokes of the scale with the reference angle created by the strokes of the same scale. This method is also called the calibration with the constant angle in the full circumference.

The methods of circular scales calibration were created and developed by such famous scientists as $\mathrm{H}$. Bruns, G. Schreiber, A. Perard, H. Wielde, Heiwelynk, 
S. Yeliseyev, etc. [1, 2, 4-6]. The "diameters" errors are determined by using those methods at angle intervals applying the control angles equal, for example, to $10^{\circ}$, $20^{\circ}, 30^{\circ}$. The angles of $36^{\circ}, 45^{\circ}$ and $60^{\circ}$ are applied by other methods of calibration. When using the methods of Heiwelynk or Yeliseyev, the full diameters errors are determined and by using Fourier series their systemic constituents are determined. The scales usually are calibrated at every $3^{\circ}$ by using those methods. Processing of the "diameters" errors by method of Bruns, linear equations of the strokes of scale position are created. The number of equations is equal to the number of angular position errors to be determined. For example, by measuring at every $3^{\circ}, 60$ equation systems are to be created. The method of Yeliseyev was the further development of the former method simplifying the number of calculation operations. The "diameters" errors are calculated determining their mean arithmetic values, and for enhancing of the accuracy of the calculations the error weight parameters are introduced. Thus, the error evaluation is stochastic, it differs from the real values of the relevant errors of the "diameters". The pitch of measurement of circular scale is not small enough, so the discretion of the stroke errors is big enough; ie it is determined at quite large intervals of the scale. Furthermore, the errors of "diameters" are determined, not the central angles of the scale. It is the reason why the comparative scales measurements are performed in machine and instruments engineering by using for the calibration other angle standards with much higher discretion of reference angle measure.

The "diameter" errors by comparison methods are determined from the period of early development of geodetic instruments. The result of measurement is calculated by using the formula

$$
A=N_{\omega}-(\omega)-N_{\varphi}+(\varphi)+B+\lambda_{1},
$$

where $A$ is the nominal angle of measurement; $N_{\omega}$ and $N_{\varphi}$ - the "diameters" of strokes created by relevant means for strokes reading, $(\omega)$ and $(\varphi)$ - errors of relevant "diameters"; $B$ - nominal (zero) value of angle (difference from the real " 0 " value); $\lambda_{1}$ - random error of measurement.

Thus, $n$ equations for measurements performed at a chosen pitch of the scale measurement, for example, $10^{\circ}$ are designed. It is accepted as $(\varphi)=0$, at the beginning of measurement, and the other errors are calculated considering that the errors are distributed evenly in the circumference. By this assumption, a value $\frac{1}{n} \sum_{i=1}^{n} \omega_{i}$ is subtracted from the results received. Such approximation is used by many authors, including the Yeliseyev method. Nevertheless, it is not accurate as the errors of different strokes and errors of the position of "diameters" are not equal and its sum is not equal to zero.

According to the main methods of scales calibration, for the calculation of scales errors, it is necessary to associate the errors determined at different angle calibration between themselves. For example, to determine the error at every $5^{\circ}$, it is necessary to calibrate the scale applying the $40^{\circ}$ and $45^{\circ}$ or $20^{\circ}$ and $45^{\circ}$ angles of the calibration. The constant angles for calibration are chosen as reiterative values to the desirable interval of calibration and such that the least difference of angles or the difference consisting of their sums and differences would be equal to the same interval [1].

Some of the earliest descriptions of the angular calibration process are the article in [4] and by Jablonski [5]. The calibration was performed using the Moore's 1440 Precision Index as angle standard and angle polygon prism of 12 sides with the autocollimator. Moore's 1440 Precision Index is an angular measuring device consisting of two serrated plates joining together to create the angle standard of measure. During the measurement the upper disk of the Index is lifted, the lower part rotates with the object to be measured, after that the upper part is lowered back and the measurement of the angular rotational error is performed by the autocollimator. The authors [5] describe the results of the mutual calibration process of the Moore's 1440 Precision Index and the polygon. The repeatability of the readings of the autocollimator did not exceed $\pm 0,02$ ". The accuracy of axis of Index rotation was $0,11 \mu \mathrm{m}$, the interval of angle measurements was $30^{\circ}$. Every position was repeated 10 times, the values of polygon calibration were in the limits between $\left(-1,6^{\prime \prime}\right.$ and $\left.+2,7^{\prime \prime}\right)$. Theoretical aspects of two calibration methods are discussed in [5]. The angular correction values are determined and mean square values of the calibration are presented.

The tests for accuracy of the comparator for the flat angle unit transfer were carried out in PTB, Germany [7]. The angular comparator WMT 220 of very high accuracy was used for the calibration of electronic autocollimators for the flat angle unit, radian, transfer according to the ISO standards. An uncertainty of 0,007" was determined as the result of calibration of the electronic autocollimators of high resolution in repeating the consecutive steps of $0,005^{\prime \prime}$ in the transfer of the standard unit of flat angle. It was stated that the calibration by very small intervals that are near to the resolution capability of the autocollimator gives an information about the possible short period bias and as consequence, making the influence to the effect of measurement by the autocollimator.

The rotary table, the standards of angle and measuring instruments are shown in Fig 1. The standards of angle as shown in Fig 1 are the most used standards in machine and instrument engineering. The items shown in the picture are: 1 - basis of the angle measuring equipment, 2 - axis of rotation, 3 - worm wheel, 4 circular scale, 5 - photoelectric microscope, 6 - angle measuring device (Moore's 1440 Precision Index), 7 mirror, 8 - autocollimator, 9 - warm glass gear, 10 multiangle prism (polygon). 


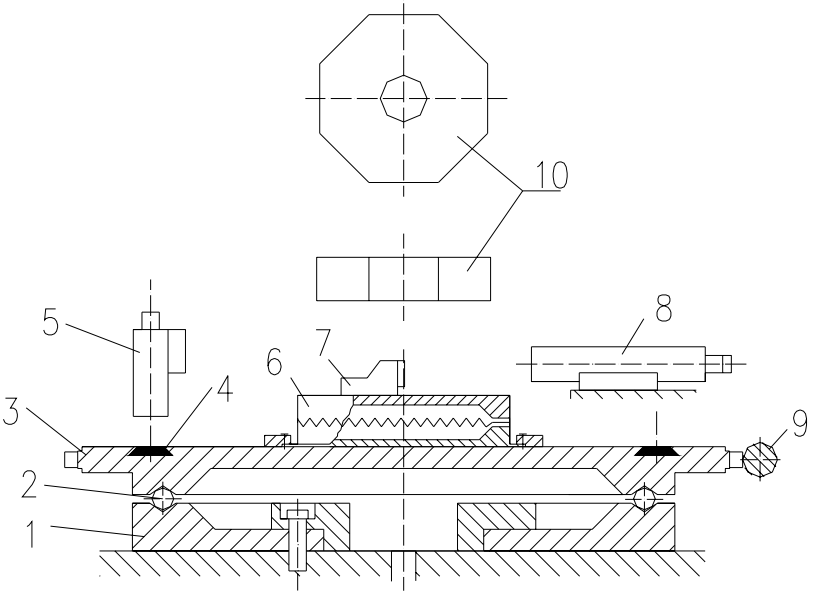

Fig 1. Arrangement for angle calibration with different angle standards

The worm gear drive is used for the transportation the object to be measured into the required position. The items $4-5 ; 6-7-8 ; 10-8$ can be chosen as the standard measure for angular displacement control. The high accuracy photoelectric transducers (rotary encoders) can be put to this range and the most advanced instrument for angular measurements - the laser gyrometer as well. When using the circular scale as the standard of measure, two photoelectric microscopes are used to avoid the influence of excentricity for the angular measurements. The advantages of rotary encoders are good possibilities for the automation of the measuring process. Some technical specifications of angle measuring devices are listed in Table 1.

Table 1. Technical specifications of angle measuring devices

\begin{tabular}{|l|l|l|r|r|}
\hline No & $\begin{array}{l}\text { Angle } \\
\text { standards of } \\
\text { measure }\end{array}$ & Discretion & $\begin{array}{l}\text { Standard } \\
\text { deviation }\end{array}$ & Bias \\
\hline 1 & $\begin{array}{l}\text { Polygon - } \\
\text { autocollimator }\end{array}$ & $\begin{array}{l}10^{\circ} ; \quad 15^{\circ} ; \\
30^{\circ}, \ldots\end{array}$ & $0,15^{\prime \prime}$ & $0,30^{\prime \prime}$ \\
\hline 2 & $\begin{array}{l}\text { Moore's 1440 } \\
\text { Precision } \\
\text { Index }\end{array}$ & $15^{\prime}$ & $0,04^{\prime \prime}$ & \pm \\
$0,1^{\prime \prime}$ \\
\hline 3 & $\begin{array}{l}\text { Circular scale- } \\
\text { microscope }\end{array}$ & $3^{\circ}, 4^{\circ}, 5^{\circ}$ & 0,2 & $\sim 3^{\prime \prime}$ \\
\hline 4 & $\begin{array}{l}\text { Photoelectric } \\
\text { rotary } \\
\text { encoders }\end{array}$ & $1^{\prime \prime} ; 0.1^{\prime \prime}$ & $\sim 0,3^{\prime \prime}$ & $\sim 1^{\prime \prime}$ \\
\hline
\end{tabular}

\section{Applying the new method for measuring circular} machines

The newly proposed method for circular scales calibration [8-11] is based on application of the $180^{\circ}$ angle created during the same measuring process as a standard measure for the circular scale calibration. Such standard can be set with the accuracy not less than $0,1^{\prime \prime}$ of the standard deviation in case of application of highaccuracy rotation axis and of high-accuracy photoelectric microscopes. The preparation for measurement and initial position are described in [11]. The measuring scheme and the principal process as the described in [11-13], is shown in Fig 2. There we present a simplified method of measurement and the main task is to demonstrate the algorithm and means for data processing.

The scale is moved by angular steps in clockwise direction, the measuring data being registered as $a_{i}, b_{i}$, $i=0,1,2, \ldots,(2 n-1) . \quad a_{i}, \quad b_{i} \quad-$ are the data of measurement by the 1 st and 2nd microscopes; $2 n-$ number of strokes in the scale.

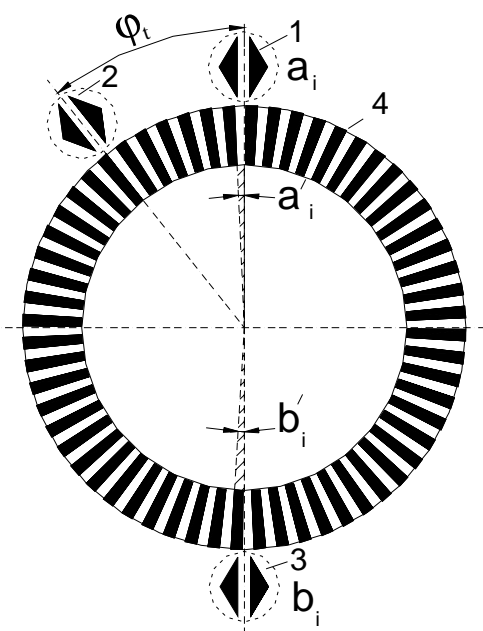

Fig 2. The diagram of measurement by determining the $180^{\circ}$ standard of angle

The microscopes 1 and 2 are set on the diametrically opposite strokes of the scale, between them the standard measure of angle $180^{\circ}$ is set. The third microscope is set on the stroke of the scale at the angle $\delta \varphi_{t}$.

The position shown in Fig 2 is: $\left|a_{i}\right|=\left|b_{i}\right|$. The initial presumption is taken [10] that $a_{0}=0 ; \delta \varphi_{0}=0$; $\delta \varphi_{n}=b_{n} ; \delta \varphi_{t}=\Delta ; \Delta$ - error of the angular position of the stroke with the index $t, \delta \varphi_{t}$ - the angle of the third microscope from the " 0 " point; $\delta \varphi_{i}$ - errors of angle of relevant strokes of the scale. The result of measurement is expressed by the system of linear equations:

$$
\left\{\begin{array}{l}
a_{0}=\delta \varphi_{0}-\delta \varphi_{t}+\Delta ; \\
b_{n}=\delta \varphi_{n}-\delta \varphi_{t}+\Delta ; \\
a_{1}=\delta \varphi_{1}-\delta \varphi_{t+1}+\Delta ; \\
b_{n+1}=\delta \varphi_{n+1}-\delta \varphi_{t+1}+\Delta ; \\
a_{2}=\delta \varphi_{2}-\delta \varphi_{t+2}+\Delta ; \\
b_{n+2}=\delta \varphi_{n+2}-\delta \varphi_{t+2}+\Delta ; \\
----------- \\
a_{2 n-1}=\delta \varphi_{2 n-1}-\delta \varphi_{2 n-1+t}+\Delta ; \\
b_{n-1}=\delta \varphi_{n-1}-\delta \varphi_{2 n-1+t}+\Delta .
\end{array}\right.
$$

Indexes of readings $b$ vary according to the number of strokes from $n$ to $(2 n-1)$, further it follows the strokes with the numbers $i=0,1, \ldots, t$. The general expression for readings will be:

$$
\left\{\begin{array}{l}
a_{i}=\delta \varphi_{i}-\delta \varphi_{i+t}+\Delta \\
b_{n+i}=\delta \varphi_{n+i}-\delta \varphi_{i+t}+\Delta .
\end{array}\right.
$$


After measuring the full circumference and by summing both sides of equations, it will yield:

$$
\begin{gathered}
\sum_{i=0}^{2 n-1} a_{i}=\sum_{i=0}^{2 n-1} \delta \varphi_{i}-\sum_{i=t}^{2 n-1+t} \delta \varphi_{i}+i \Delta ; \\
\sum_{i=0}^{n-1} b_{i}=\sum_{i=n}^{n-1} \delta \varphi_{i}-\sum_{i=t}^{2 n-1+t} \delta \varphi_{i}+i \Delta \\
\text { For both equations } \\
\sum_{i=0}^{2 n-1} \delta \varphi_{i}-\sum_{i=t}^{2 n-1+t} \delta \varphi_{i}=0, \text { then } \\
\Delta=-\frac{1}{i} \sum a_{i} .
\end{gathered}
$$

Further the equations can be solved in respect to both $a_{i}$ or $b_{i}$. There must be noted that according to [11] various possibilities are available including the determination of the "diameters" errors using the expressions (1), (2). Here the calculations will be demonstrated according to expressions of $a_{i}$ by the formula (4). Theoretically, it is possible to measure and determine the errors of every stroke in the circular scale, albeit a great number of strokes is present. It is very important nowadays, as the circular scales are made of very small diameter having thousands of strokes in the scale. It is impossible to perform such measurements by using the known circular scales calibration methods. Applying an axis of rotation based on aerostatic bearings and using the microphotoelectric reading devices, the real possibility for its implementation exists. The errors determination functions consisting of great number of equations also present a problem as usually applied software is not quite fit for this. By measuring the scale at every $1^{\circ}$, the equation system of 360 members will be created; by measuring the scale at every $1 / 3$ degree it will be 1080 , etc. The raster scale having 21600 strokes will require the same number of equations to be solved for the error determination.

The Mathematica 5 software package was used for this purpose.

\section{Applying software for calculating results}

With the help of Mathematica 5 a linear equation system $\boldsymbol{A} x=\boldsymbol{b}$ is solved, where $\boldsymbol{A}$ is an $n \times n$ matrix, while $x$ and $\boldsymbol{b}$ are $n \times 1$ vectors. In the code for solving the problem $\boldsymbol{A}$ is called left, and $\boldsymbol{b}$ - right. Mathematica software has been chosen for its capabilities to seamlessly expand linear equation systems up to hundreds of thousands of unknowns as well as for the simplicity of performing calculations with them. These capabilities are demonstrated and discussed below.

The rules are created according to which a sparse matrix is constructed. A sparse matrix is a matrix the majority of members of which are equal to zero. In this case the diagonal is filled in with ones, and the diagonal above the main diagonal is populated with -1 . In other words, $a_{i i}=1$ and $a_{i j}=-1, i=1, \ldots, n ; j=i+1$. It depends on coefficients $\delta \varphi_{i}$ and $-\delta \varphi_{i+t}$ in formula (4). In the command code below, $i$ and $j$ represent the indices of matrix rows and columns. On the main diagonal these values are equal, and for the diagonal just above the main diagonal, the row index is one less than the column index: matrix_rules $=\left\{\left\{i_{-}, i_{-}\right\} \rightarrow 1,\left\{i_{-}\right.\right.$, $\left.\left.j \_\right\} / ; \bar{j}-i==1 \rightarrow-\overline{1}\right\}$

Following the rules of populating a matrix set earlier, a $16 \times 16$ sparse matrix is created:

left
Normal [SparseArray [matrix_rules, $\{16$,
$16\}]$ ]

A $16 \times 16$ sparse matrix created according to the rules set earlier is displayed below. The rows of the sparse matrix are as follows:

$\{\{1,-1,0,0,0,0,0,0,0,0,0,0,0,0,0,0\},\{0,1,-1,0,0,0,0,0,0,0,0,0,0,0,0,0\}$, $\{0,0,1,-1,0,0,0,0,0,0,0,0,0,0,0,0\},\{0,0,0,1,-1,0,0,0,0,0,0,0,0,0,0,0\}$, $\{0,0,0,0,1,-1,0,0,0,0,0,0,0,0,0,0\},\{0,0,0,0,0,1,-1,0,0,0,0,0,0,0,0,0\}$, $\{0,0,0,0,0,0,1,-1,0,0,0,0,0,0,0,0\},\{0,0,0,0,0,0,0,1,-1,0,0,0,0,0,0,0\}$ $\{0,0,0,0,0,0,0,0,1,-1,0,0,0,0,0,0\},\{0,0,0,0,0,0,0,0,0,1,-1,0,0,0,0,0\}$, $\{0,0,0,0,0,0,0,0,0,0,1,-1,0,0,0,0\},\{0,0,0,0,0,0,0,0,0,0,0,1,-1,0,0,0\}$. $\{0,0,0,0,0,0,0,0,0,0,0,0,1,-1,0,0\},\{0,0,0,0,0,0,0,0,0,0,0,0,0,1,-1,0\}$, $\{0,0,0,0,0,0,0,0,0,0,0,0,0,0,1,-1\},\{0,0,0,0,0,0,0,0,0,0,0,0,0,0,0,1\}\}$

Next, the matrix created can be displayed in a traditional form. Real measurement results provide $a_{i}$ values, and a vector of these values is created:

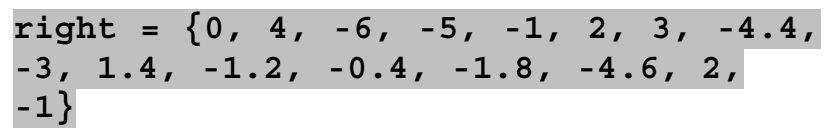

The software confirms the vector created by repeating the values entered:

$\{0,4,-6,-5,-1,2,3,-4.4,-3,1.4,-1.2,-0.4,-1.8,-4.6,2,-1\}$

Using formula (7) $\Delta$ is calculated (an average value of all elements of the vector above), which is later subtracted from each member of the result vector thereby receiving vector $\mathbf{b}$. In the program code $(a-=b)$ means $(a$ $=\mathrm{a}-b)$ :

\section{right $-=$ (Total [right] /Length [right])}

$\{1 ., 5 .,-5 .,-4 ., 0 ., 3 ., 4 .,-3.4,-2 ., 2.4,-0.2,0.6,-0.8,-3.6$, $3 ., 0$.

Then the linear equation system $\mathbf{A x}=\mathbf{b}$ is solved: LinearSolve[left, right]

And the result vector $\boldsymbol{x}$ is displayed: $\{0 .,-1 .,-6 .,-1 ., 3 ., 3 ., 0 .,-4 .,-0.6,1.4,-1 .,-0.8,-1.4,-0.6$, 3.,0. $\}$

To illustrate the solution in a more straightforward fashion we present a relatively small matrix with 16 unknowns - angle error values from measurement results to be found. Calculations with $360 \times 360$ and $1080 \times 1080$ matrices have also been performed. Vector $\mathbf{b}$ or right has 
been generated from random numbers. An example with a 360 element vector follows:

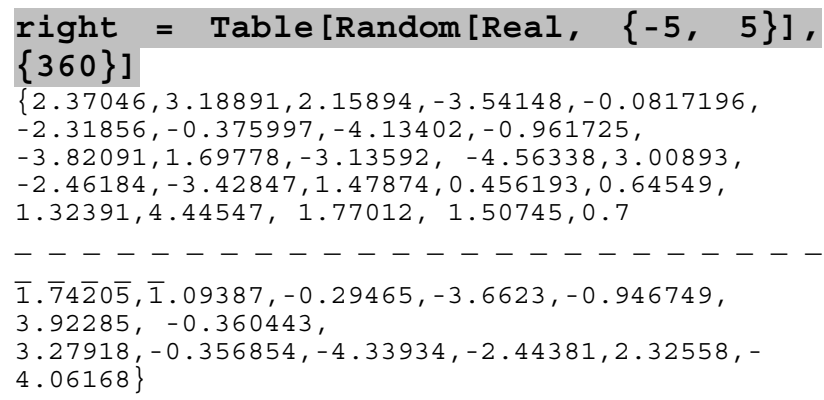

In this example 360 floating point values are generated in the interval of $[-5,5]$. Vectors and matrices of 1080 values are formed in an analogous way. This solution method is convenient because it is possible to create a coefficient matrix of the size of your choice on the left side of the equation. In spite of a rapidly increasing amount of data, Mathematica software provides the solution quickly.

Because of a large quantity of information, only a $16 \times 16$ matrix has been displayed. Operations with more data do not introduce anything substantially new; only some parameters in the instruction code need to be changed. After the solution process, which takes place noticeably longer, it makes sense to output only the final results in row or table format as instructed. The capabilities of calibrating circular scales can be validated by computer modelling described in $[12,14,15]$.

Using a circular scale as a referential standard, a multivalue device for an easily conveyed angle calibration of high discreteness and accuracy or even a standard of a flat angle can be created. The optimal structure of a flat angle calibration bench could possess these technological characteristics (Table 2).

Table 2. Accuracy and technical parameters of the test bench for the flat angle calibration

\begin{tabular}{|l|l|l|}
\hline No & \multicolumn{1}{|c|}{ Structural elements } & Parameters \\
\hline 1 & Hardware & $\begin{array}{l}\text { Rotary table with the axis, } \\
\text { circular scale, micro- } \\
\text { scopes, autocollimator } \\
\text { and polygon }\end{array}$ \\
\hline 2 & Total run-out of axis, $\mu \mathrm{m}$ & $0,05 \ldots 0,1$ \\
\hline 3 & Number of scale strokes & $1080\left(\varphi_{\mathrm{t}}=20^{\prime}\right)$ \\
\hline 4 & Width of the strokes, $\mu \mathrm{m}$ & 5 \\
\hline 5 & Microscopes & photoelectric \\
\hline 6 & $\begin{array}{l}\text { Standard deviation of the } \\
\text { microscopes, } S, \mu \mathrm{m}\end{array}$ & 0,05 \\
\hline 7 & Multiangle polygon & $12-24$ angles \\
\hline 8 & $\begin{array}{l}\text { Accuracy parameters of } \\
\text { the angles of the polygon }\end{array}$ & $S=0,03 ; P=0,99$ \\
\hline 9 & $\begin{array}{l}\text { Autocollimator } \\
\text { Measurement range } \pm 10^{\prime} ; \\
S=0,02 ; P=0,99\end{array}$ \\
\hline 10 & $\begin{array}{l}\text { Pitch of angular } \\
\text { positioning of the rotary } \\
\text { table, degrees }\end{array}$ & $1^{\prime} ; 10^{\prime} ; 20^{\prime} ; 1^{\circ} ; 3^{\circ} ; 10^{\circ}$ \\
\hline
\end{tabular}

The above-mentioned technical specifications parameters show a technical possibility to create a angle calibration bench of a very high accuracy. Such equipment can also be used for the calibration of geodetic instruments and machine engineering devices. It is possible to calibrate the angle measuring devices of the accuracy equal to $\sim 3$ ". The discretion of the calibration is also easily achieved, and such a feature gives a possibility to calibrate the angle standards and instruments which have $10^{\mathrm{n}}$ or $2^{\mathrm{n}}$ strokes or signals per revolution.

\section{Conclusions}

1. An analysis of methods and means for the precision angle measurement is presented in the article. A practical implementation of the method based on using the half of the full angle is also explained in detail. The algorithm for solving a great number of equations is developed. For its solution the Mathematica software package was applied. Practical results of solutions are demonstrated, the possibilities for solving the equations with more number unknowns is also shown.

2. The data presented lead to the conclusion that by using the special circular scale as the standard measure of angle, it is possible to create the standard measure of flat angle of high accuracy, stability and discreteness and the calibration arrangement as well assuring the transfer and the traceability chain with the state and international standards of the flat angle unit.

\section{References}

1. Jelisejev, S. V. Geodetic instruments and devices. Basic principles of design, calculations and production features (Геодезические инструменты и приборы. Основы расчета, конструкции и особенности изготовления). Moscow: Nedra, 1973, 392 p (in Russian).

2. Petrov, V. P. Testing and control of geodetic instruments (Контроль качества и испытание оптических приборов). Leningrad: Mašinostrojenije, Leningradskoe Otdelenije, 1985. 222 p (in Russian).

3. GOST 13424. Theodolites. Methods for determination of errors of horizontal circle diameter. (ГОСТ 13424. Теодолиты. Методы определения погрешностей диаметров горизонтального круга). Moscow: Publishing house of standards, 1983. 102 p (in Russian).

4. Giniotis, V. Brief review of methods for measuring of circular scales. Geodesy and Cartography (Geodezija ir kartografija), No 2 (26), Vilnius: Technika, 1997, p 21-25.

5. Jablonski, R.; Shimokohbe, A. and Nagai, A. Calibration system for precision angle standards. Bull. P. M. E. (T. I. T.), No 45, 1980, p 17-24.

6. Cook, A. H. The calibration of circular scales and precision polygons. Br. J. Appl. Phys., 5, 1954, p 367-371.

7. Giniotis, V.; Murauskas, G. Development of methods for intelligent measurement of the raster scales. XIV IMEKO World Congress. New Measurements - Challenges and Visions. In: Proceedings of XIV IMEKO World Congress, Vol 8, 1997. Helsinki, 1997, p 234-239.

8. Patent SU 1775038, Int Cl G 01B 11/00. Device for measurement of the errors of the strokes of circular scale / V. Giniotis, A. Augustaitis, G. Murauskas. - July 1992 (Патент 1775038 СССР, МК И G 01 В $11 / 00$. Устройство для измерения погрешности штрихов лимба. В. П. Гинетис, А. И. Аугустайтис, Г. Г. Мураускас. 1992, июль) (in Russian). 
9. Just, A.; Krause, M.; Probst, R. and Wittekopf, R.. Calibration of high-resolution electronic autocollimators against an angle comparator. Metrologia, 40, 2003, p 288 294.

10. Giniotis, V. The methods and means for measurement of length and angles. Abstract. Vilnius: Technika, 1995. 55 p.

11. Giniotis, V. and Grattan, K. T. V. Optical method for the calibration of raster scales. Measurement, 2002, Vol 32/1, p 23-29.

12. Giniotis, V. and Rybokas, M. Data processing and information assessment in scales measurement simulation. In: Proceedings of XVII IMEKO World Congress, 2003, p 1053-1056.

13. Giniotis V. Investigations in the field of length and angle measurements. In: Science and arts of Lithuania. Vibroengineering (Lietuvos mokslas. Virpesių mechanika ir technika). Monography. Vilnius: Lietuvos mokslų akademija, 1998, p 156-168.

14. Giniotis, V.; Marčiukaitis, G. Computer simulation of scales measurement. Geodesy and Cartography (Geodezija ir kartografija), Vol XXV, No 1, Vilnius: Technika, 1999, p 3-8.

15. Petroškevičius, P. Gravitation field effect on geodetic observations. (Gravitacijos lauko poveikis geodeziniams matavimams). Vilnius: Technika, 2004. 292 p (in Lithuanian).

\section{KAMPŲ KALIBRAVIMO TIKSLUMO TYRIMAS}

\section{Giniotis, M. Rybokas, P. Petroškevičius}

\section{S a n trauka}

Straipsnyje nagrinejjamos techninès galimybès sukurti plokščiojo kampo kalibravimo įrenginį tiksliems kampų matams kalibruoti. Plokščiojo kampo vienetas radianas iki šiol nėra laikomas kampo mato etalonu. Kampo matas laipsniais gali būti nesunkiai sukuriamas ir atkartojamas geodezijoje taikant geometrinius ilgio matus, o mašinu gamybos ir kt. pramonès šakose - naudojant daugiakampes prizmes (poligonus) su autokolimatoriais, pasukamuosius optinius stalus, apskritimines skales ir pan.
Reikia pažymėti, kad plokščiuju kampų matai kalibruojami tik retais intervalais, tiek, kiek turi briaunų daugiakampé prizmè arba kitas pirminis matas, taikomas kaip etalonas. Taip pat šiam tikslui yra taikomi pastovaus kampo kalibravimo visame apskritime metodai. Geodeziniams prietaisams, stakliu pasukamiesiems stalams ir keitikliams būdinga didelis rodmenų diskretumas. Jų tarpinè verté bei paklaidos lieka nenustatytos, taip pat išlieka daug nežinomos informacijos vertinant informacinès entropijos metodu. Didesnio diskretumo ir reikiamo tikslumo plokščiojo kampo kalibravimo įrenginys padètų užtikrinti didesni gaminių, statybinių darbǔ bei geodezinių matavimu tikslumą ir informatyvumą. Čia pateikiamas teorinis ir techninis plokščiojo kampo kalibravimo irenginio tikslingumo pagrindimas ir, remiantis turimu techniniu bei moksliniu potencialu, aptariamos jo sukūrimo galimybės,

Raktažodžiai: kalibravimas, apskritiminė skalè, etalonas, kampas, tikslumas 